\title{
Does information increase political support for pension reform? *
}

\author{
Tito Boeri Guido Tabellini \\ Bocconi University and IGIER
}

First draft: July 2005

This draft: October 2005

\begin{abstract}
$\underline{\text { Abstract }}$
An opinion poll on a representative sample of Italian citizens suggests that it does. We focus on reforms that would lengthen retirement age and /or cut pension benefits. After controlling for individual features of the respondent, we find that individuals who are more informed about the costs and functioning of the Italian pension system are more willing to accept reforms. This result holds also using non-parametric methods, such as propensity-score matching. However, the data also suggest that information is endogenous, and jointly determined with policy opinions. We therefore estimate a causal effect of information, with joint maximum likelihood and instrumental variables. These different methods all confirm a positive and significant causal effect of better information on the willingness to accept reforms that reduce the generosity of the pension system. Finally we do not find that exposure to media coverage of pension issues significantly improves information, possibly because individuals read newspaper articles or watch TV programs on these issues just to confirm their priors.
\end{abstract}

JEL classification codes: H55. J26, D8.

Keywords: Pension reform, information, policy opinions.

\footnotetext{
* We are grateful to Paola Monti for excellent research assistance, to Bocconi University, CIAR, Fondazione Rodolfo Debenedetti and the Italian Ministry of University and Research for financial support, and to participants to a CEPR Public Policy Seminar at Bocconi University for helpful comments.
} 


\section{Introduction}

Why is it so difficult to reform the unsustainable and overly generous European pension systems? A simple answer is that a majority of elderly European voters wants to gain at the expenses of younger or future generations. But this is not fully convincing, as it presupposes that voters are egoistic and do not care about their offspring. This paper explores the role of a second possible answer: opposition to pension reform also stems from lack of information about the true costs of the pension system, and lack of understanding of the consequences of “pay as you go” public pensions.

We study empirically the opinions of a representative sample of Italian citizens about the desirability of alternative pension reforms. Lack of information about basic features and costs of public pensions is widespread. Our central finding is that better information is associated with more willingness to accept reforms. Of course, individual information is not random. The correlation between individual information and policy preferences could reflect an unobserved common determinant (such as wealth, or family background). Measurement errors may also make information endogenous to policy preferences. The main contribution of this paper is to show that, under a range of alternative identification assumptions, the estimated correlation reflects a causal effect: informed individuals are more willing to accept pension reforms because of their better information about the costs and consequences of the pension system.

If valid, this conclusion would have important policy implications. To increase public support for pension reforms, governments in countries with large and unsustainable public pension systems ought to devote more effort and resources to inform citizens about the basic functioning of pay-as-you-go pensions, about its actual costs, and the net position of individual contributors. But media coverage, by itself, may not be sufficient to inform citizens. We find that individuals who have read newspaper articles or watched TV debates on pension reform are not better informed than the other citizens. Governments who seriously want to improve citizens' knowledge about the consequences of public pensions ought to find other ways to convey information to voters. The concluding section discusses some concrete examples drawing from the experience of Sweden.

The implications of our findings go beyond the pension system. A standard assumption in political economics is that voters can evaluate the implications of alternative policy proposals, and that they know which policy alternatives are in their best interest. The empirical results of this paper cast doubts on the validity of this assumption. Not only voters are vastly uninformed, but their lack of information has a systematic impact on policy preferences and induces a bias in favour of the status quo. Whatever determines voters' information is an important determinant of policy preferences, and hence of the policies that ultimately get implemented by politicians.

We are not the first to point out the role of information in shaping policy preferences on pension reforms. Boeri, Boersch-Supan and Tabellini (2001), (2002), drawing on surveys of European citizens, pointed to i) a systematic overestimation of benefits and 
underestimation of costs of public pension systems and ii) a positive correlation between the support to reforms allowing for a partial privatisation of pension systems and a correct information about the net costs of social security. Blinder and Krueger (2004) studied opinion polls in the US, and also noted that more informed individuals are more likely to support pension reforms. These papers, however, assumed that the attribute of being informed was exogenous, and did not fully investigate the possible joint determination of policy preferences over a variety of reform options and information acquisition.

The outline of the paper is as follows. Section 2 illustrates the estimation strategy. The data are defined in section 3. Section 4 estimates the effect of information on policy opinions assuming that information is exogenous, using parametric and non-parametric (propensity score) methods. Section 5 relaxes the exogeneity assumption, and estimates a causal effect of information by means of instrumental variables and joint maximum likelihood methods. Section 6 discusses the role played by the media in learning about the true costs of pension systems. Section 7 summarizes and concludes.

\section{General estimation strategy}

Our goal is to estimate an equation of the following type:

$$
Y_{i}=F\left(X_{i}, I_{i}\right)+e_{i}
$$

where $Y_{i}$ is a binary variable that measures the policy opinions of individual $i, X_{i}$ denotes his general attributes (such as age, education, gender, and so on), $I_{i}$ is a measure of how informed he is about the costs and the functioning of the pension system, and $e_{i}$ is an unobserved error term. We are interested in the effect of information on policy preferences.

We view information as determined by an equation of the following type:

$$
I_{i}=G\left(X_{i}, Z_{i}\right)+u_{i}
$$

where $Z_{i}$ is a set of additional observable individual features that determine the information possessed by each individual, and $u_{i}$ is an unobserved determinant of information.

Our first step is to assume that the error terms $u$ and $e$ are uncorrelated, and that $Z_{i}$ is uncorrelated with both $e_{i}$ and $u_{i}$. In this case, the model is recursive and we can treat information as exogenous in equation (1). We also check whether our estimates are robust to alternative assumptions about the functional form $F($.). In particular, the effect of information on policy opinions could interact with other individual attributes, such as

age or income. For instance, older vs young individuals have opposite economic interests on pensions, and so better information about the functioning of pension systems could induce opposite reactions in these two groups. To cope with this 
problem, we also estimate (1) by means of non-parametric methods based on the propensity score. These estimates assume again exogeneity of information, after conditioning on the variables in $X$, but allow the functional form $F($.$) to be totally$ unrestricted.

Under additional assumptions, the recursivity assumption can be tested. We do it, and we reject it. This means that some unobserved individual features determine both the preferences and the information of individuals. Assuming exogeneity, in this case, would lead to biased estimates of the coefficients of interest. We cope with this problem in two ways.

First, we allow $e$ to be correlated with $Z$ and $u$, but we assume that $e$ and $u$ are jointly normally distributed and that $F($.$) and G($.$) are linear. Under this functional form$ assumption, and measuring information (I) also as a binary variable, we can jointly estimate (1) and (2) by means of maximum likelihood methods. Here we achieve identification by making strong assumptions about the functional forms $F($.) and $G($.$) .$

Second, we achieve identification via exclusion restrictions. In particular, we assume that the variables $Z$ are uncorrelated with $e$, the error term of the policy opinions equation. Under this exclusion restriction, $Z$ is a valid instrument for information, $I$, and we can estimate by instrumental variables by linearising equations (1) and (2).

If both estimation methods give similar results, we are reassured that our inferences are robust.

\section{Data}

\subsection{The survey}

The survey was carried out by Carlo Erminero \& Co. in March 2004 over a representative samples of 1500 Italians aged 16 to 80 out by means of Computer Assisted Telephone Interviews (CATI). In addition to the standard set of socioeconomic background variables such as age, education, and income, the questionnaire included questions that elicited the information and the preferences about the current pension systems and potential reform options. The questionnaire is in Annex 4. Compared to existing surveys on the same issues, we do not ask open questions ("Do you want more benefits?”), but we posed specific trade-offs among specific policy options ("Are you willing to pay $\mathrm{x} \%$ higher contributions in order to obtain $\mathrm{y} \%$ higher benefits”). These type of questions are in the tradition of "contingent valuation”, and we use the "stated preference" questionnaire techniques described in Louviere, Hensher and Swait (2000).

A common difficulty faced when asking about opinions is that answers to such questions are particularly prone to framing biases. For this reason, we tried to avoid suggestive formulations. Where we wanted to ascertain the individual's answer on what is good for her or him, rather than on what she or he thinks is good for society at large, 
we took great care in describing the applicable situation for the respondent and the corresponding offers in detail. Finally, we tried to avoid hypothetical situation bias by anchoring the answers around realistic numbers, e.g., pension benefit levels, and by varying potential answers by socio-economic situation, e.g., between employed and unemployed.

Table 1 provides summary statistics of all the variables used in the paper. A precise definition of these variables is in Annex 3. We now turn to a discussion of the main variables of interest.

\section{(insert Table 1 about here)}

\subsection{Opinions on reforms}

Opinions on pension reform (the variable $Y$ above) are summarized in a single variable. We exploit two questions eliciting opinions about hypothetical reforms that would reduce the size of the public pension system via an increase of the retirement age or a reduction of pension benefits (see Annex 4 for a precise formulation of the questions). The dummy variable shrink equals 1 if the respondent is either in favor of increasing the retirement age or of reducing pension benefits, independently of the answer provided to the other question. Shrink takes the value zero instead if the respondent is strictly against one of the two reforms and does not approve the other. Shrink takes the value zero instead if the respondent is strictly against one of the two reforms and does not approve the other. Thus, we only focus on reforms that would reduce the size of pension expenditures, leaving aside pension reforms that increase social security contributions. Inspection of the first line of Table 1 indicates that less than 40 per cent of the individuals taking a stance on these reforms was favorable to either cutting benefits or increasing retirement age, or both.

About 50 individuals out of 1500 answer don't know / no answer to both questions. These individuals are treated as randomly missing throughout. To check that this censoring does not induce selection bias, Annex 1 reports estimates of a model with censoring on the binary variable shrink, with a Heckman two step procedure that allows for non-randomly missing observations. Annex 1 also estimates a multinomial logit specification, where the dependent variable can take three values (the third possible value being those that answer don't know / no answer to both questions). The results are similar to those displayed in Table 2 below.

\subsection{Information}

We measure information about individual and aggregate costs of pension systems (the variables $I$ above) by means of several indicators.

Info_deficit is a dummy variable equal to one if the respondent is aware of the fact that the pension system is in deficit (the sum of contributions is lower than the sum of all 
pensions being paid) and zero otherwise. This variable is available for all respondents. As shown in Table 1, about $65 \%$ of the respondents know that the system is in deficit.

Info_payg is a dummy variable equal to one if the respondent understands that current pension benefits are paid out of social security contributions of currently working individuals, and zero otherwise. This question has only been asked to the respondent holding a job, and hence contributing to the public pension system at the time of the interview. Here, the data reveal more ignorance: about half of the respondents understand the basic functioning of a pay-as-you- go pension system. Such a low rate could also reflect a misunderstanding of the question, which however was quite straightforward (see Annex 4).

Finally, Info_rate is a dummy variable equal to one if the respondent is aware of the percentage of her/his wage that goes to pay pension contributions, adding up the contributions paid by employer and employee (we chose a large interval, $25 \%-40 \%$, around the correct answer of 32,7\%). Only employees were asked this question. Despite the generous interval for a correct answer, only about $25 \%$ of respondents answer correctly according to our definition and less than $10 \%$ state that the contribution rate is in the 30 to $35 \%$ range. Hence, there is huge misinformation about the true costs of public pensions ${ }^{1}$. Note that here respondents are only the employees, not the public at large; presumably employees are more informed about what they pay into the system, compared to individuals out of the labor force or unemployed. Yet, more than one respondent out of two does not know the answer ${ }^{2}$, another 12 per cent underestimates the true contribution rate while only about 4 per cent overestimates it.

We also defined variables combining information on various dimensions. In particular, the variable info2 is the sum of info_deficit and info_payg, and thus it measures the number of correct responses to the questions used to code these two variables. Finally, the variable info3 is the sum of info_deficit, info_payg and info_rate, and thus measures the number of correct responses referring to these three variables. Clearly, given the pattern of the survey, info2 and info3 could only be computed for employed and employees respectively.

\subsection{Other variables}

Throughout the analysis, we condition on several observable features of the respondent that are likely to influence his policy preferences (the variables $X$ above), such as his education, age, gender, type of occupation, ideology, and so on. All these variables are defined precisely in Annex 3.

\footnotetext{
${ }^{1}$ Jappelli, Padula and Bottazzi (2003) also found that Italians overestimate the level of benefits at retirement as they have not yet internalised the effects of the pension reforms of the 1990s.

2 This is roughly the same percentage of "don't know" answers which was obtained asking the same question in 2000 and 2001 to a representative sample of Italians. Importantly, the percentage of individuals underestimating the contribution rate is increasing over time. Thus, there is no indication that Italians are learning about the costs of their pension system.
} 
Finally, as instruments for information (the variables $\mathrm{Z}$ above) we rely on a variable noclue, which counts how many times the respondent answered "I don't know" to some other questions of the survey. Some of the questions used to construct noclue elicit opinions about the sustainability of the pension system, the desirable size of the welfare state and the way in which politicians, unions, experts and EU bureaucrats represent the interests of respondents; the remaining questions seek to capture knowledge of specific features of the welfare state. The variable noclue ranges from 0 to 13, with a mean of 2 and a standard deviation of 2.2. See Annex 2 for a list of the relevant questions used to construct noclue. The results below are robust to a more restrictive definition of noclue, e.g., computed by considering only the set of positive questions on the features of the welfare state, or dropping subsets of the remaining questions. As we shall see below, noclue is strongly correlated with the indicators of individual information. Moreover, after conditioning on other individual features, there is no strong a priori reason why this variable ought to be systematically correlated with unobserved determinants of attitudes in favor or against pension reforms. If so, it can be used as valid instrument for information. We further discuss the identification assumption in context, when commenting on the results.

\section{$4 \quad$ The model with exogenous information}

As stated above, we start by studying the determinants of opinions on pension reforms, assuming that the attribute of being informed is exogenous. In terms of equations (1) and (2) in section 2, this amounts to assuming that the unobserved determinants of policy opinions and information (the error terms $u$ and $e$ ) are uncorrelated. Hence, in this section we only report estimates to equation (1), neglecting equation (2).

\subsection{Parametric estimates}

Table 2 displays the probit estimates. The sample consists of all respondents in column 1 , of employed individuals in column 2, and of employees in column 3 . The last three rows report the estimated coefficients of interest on the variables measuring information, namely info_deficit, info2 and info3. The remaining rows report the estimated coefficients of the other controls. The estimated coefficients on the information variables are robust to alternative specifications of the set of controls.

\section{(insert Table 2 about here)}

Not many control variables have statistically significant estimated coefficients, perhaps because of multicollinearity. Ideology plays an important role in shaping preferences: individuals with a right wing ideology (id_right) are more likely to favour pension reforms. Those advocating a stronger role of trade unions in the pension reform debate (unioninfl) are more likely to oppose reforms, while those advocating a stronger role of experts (expertinfl) are more supportive. Individuals belonging to households where the main income earner has middle to low occupational status (the variables bluecollar and whitecollar include clerical and unskilled workers, and exclude professionals and

middle to high managers) are less likely to favour reforms. Surprisingly, age does not 
appear to be a significant determinant of policy preferences, perhaps because of collinearity with other variables (such as "Dini", a dummy capturing the young generations involved in the less generous regime introduced with the Dini reform in 1996). The pseudo R2 (the improvement in the likelihood associated with the inclusion of the covariates in addition to a constant) is larger when the sample includes only the employed persons.

The important role of ideology in explaining policy opinions is consistent with the results of Blinder and Krueger (2004) for the US. Citizens' opinions seem to reflect ideological stereotypes or prejudices about whom to trust (whether experts vs trade union leaders), rather than economic self-interest. The finding that age does not explain policy preferences on pensions is more surprising, however, and contradicts earlier findings by Boeri, Boersch-Supan and Tabellini (2001, 2002).

The main result displayed in Table 2 is that information emerges as an important determinant of policy preferences. Better informed individuals are more likely to favour reforms, rather than to oppose them. As indicated by the dprobit coefficients reported for the three key variables of interest, knowledge of the fact that the pension system is in deficit increases the probability of being in favour of reforms in the reference group (non-employed middle-aged women with secondary educational attainments) by 8 per cent. Thus, information about sustainability, costs and functioning of social security has a non-neutral effect on policy opinions.

In interpreting this result, it is important to stress the content of information. Two out of three information variables refer to the costs (how much individuals pay into the system) or the sustainability of public pensions (whether the system is in deficit). As expected, individuals who are more ignorant about the costs or about the pension deficit are more likely to oppose reforms. ${ }^{3}$ The third information variable reflects basic understanding of the pay-as-you-go system. A priori the effect of this variable could go either way. According to the estimates, individuals who confuse pay-as-you-go with a fully-funded system are also more likely to oppose reforms. Perhaps this can be interpreted as evidence that individuals who mistakenly believe that their pensions are paid out of their own past savings feel more entitled to receive higher compensations.

Our definition of the variable Shrink also raises a subtle issue. By construction, someone who approves of one of the two hypothetical reforms and replies don't know / no answer to the second option is classified as in favor of reforms (Shrink =1). Conversely, someone who rejects one reform and replies don't know / no answer to the second one is classified as being against the reforms ((Shrink $=0)$. It turns out that the distribution of don't know /no answer is not symmetric around these two possible combinations. In our sample the pair "reject \& don't know" is more frequent than the pair “approve \& don't know”. This pattern could introduce a spurious correlation between lack of information and rejection of reforms. To cope with this problem, we

\footnotetext{
${ }^{3}$ Note that we control for whether individuals expect an imminent crisis in the pension system (in Table 2 the variable crisis has a positive but insignificant estimated coefficient). Thus, awareness of the deficit plays an important role in shaping public opinion, irrespective of whether they expect an imminent crisis.
} 
have also redefined the variable Shrink excluding don't know and no answers to either the question on retirement age or that on pensions; thus we have redefined Shrink $=1$ if the respondent approves both reform options, or approves one and rejects the other; and we have redefined Shrink $=0$ if the respondent rejects both reforms. Now the number of missing observations increases from about 50 to about 200. To check that these missing individuals don't create a selection bias, we have then re-estimated the model with a Heckman two-step procedure that allows for censored observations. The results (reported in Annex 1) confirm those reported in Table 2.

Finally, a natural question is whether the effect of information varies with individual characteristics, such as age, education and ideology. A priori, knowledge about a redistributive program like pensions could have very different implications for policy preferences, depending on the individual situation. Table 2 already provides a first negative answer to this question. The estimated effect of information is very similar in the three columns of Table 2, that correspond to different categories of individuals: all adults, only employed individuals, and only employees in columns 1, 2 and 3 respectively. We also interacted the information variables with several other controls. We found no significant and systematic pattern, suggesting that information affects policy preferences independently of individual characteristics. Nevertheless, there is a limit to the kinds of interactions that can be imposed on the data parametrically. The next subsection thus discusses more general estimation methods.

\subsection{Matching estimates}

To relax linearity or other parametric functional forms, here we estimate the effect of information on policy opinions by means of semi-parametric methods. In this subsection we retain the assumption of exogeneity of information, or conditional independence as defined on the literature on the treatment effect: after conditioning on the variables discussed below, information is uncorrelated with other unobserved determinants of policy opinions.

Since these non-parametric methods are not very efficient, and their small sample properties not well known, we confine attention to the full sample of almost 1500 individuals. Information thus refers to knowing that the pension system is in deficit (info_deficit). Policy opinions are measured by the dichotomous variable shrink, that disregards the don't know / no answer to both reform dimensions.

As a first step, we regress info_deficit on a set of control variables, estimating by probit an equation including all the covariates used in the estimation reported in Table 2. Our maintained assumption is that, after conditioning on these variables, information is exogenous with respect to policy opinions.

Next, from this first stage estimation, we compute the predicted probability of being informed, for every individual in our sample. This predicted probability is called the "propensity score". It measures how likely each individual is of receiving the "treatment" of being informed. Some of these individuals are actually informed (for 
them info_deficit equals one), while others are not (info_deficit equals zero). To reduce the role of outliers, we drop extreme observations, imposing the common support assumption. ${ }^{4}$ This leaves us with 1445 observations. Figure 1 illustrates the estimated propensity score for the remaining informed and uninformed individuals. The distribution is shifted to the right for the informed individuals, as it should be, but the probability mass is generally high over a large range of values for the propensity score.

\section{(insert Figure 1 about here)}

Our final step is to estimate the effect of information on policy opinions, by comparing the values of the dependent variable shrink for informed and uninformed individuals, but giving more weight to the comparison of individuals with similar propensity scores. This non-parametric method estimates the average treatment effect, and thus it is not directly comparable to the estimated coefficient of info_deficit reported in Table 2 under the probit specification. Compared to the estimates reported in the next section, here we do not make any assumption about the second stage functional form.

Table 3 reports the estimated coefficient of interest, for three alternative weighting methods: stratification, nearest neighbor matching with random draw, and nearest neighbor matching with equal weights. ${ }^{5}$ The effect of information is positive and statistically significant, particularly with the stratification method. Overall, the matching estimates confirm that the positive average effect of information on willingness to reform is robust to any possible kind of interaction.

\section{(insert Table 3 about here)}

\section{Endogenous information gathering}

In this section we first test the exogeneity of the information gathering process. Once established that we can reject it, we cope with joint determination of policy opinions and information in two ways: first, we estimate a joint model of policy opinions and information by means of maximum-likelihood, assuming that both probabilities are distributed as a normal; second, we estimate a linear specification of policy opinions with instrumental variables for information.

\subsection{Is information exogenous?}

\footnotetext{
${ }^{4}$ That is, after ranking individuals based on their propensity score, we drop all uninformed individuals with propensity score higher than the first informed individual; and we drop all informed individuals with propensity score lower than the last uninformed individual.

${ }^{5}$ The stratification method divides the range of variation of the propensity score in intervals such that within each interval treated and control units have similar propensity scores. The nearest neighbor method applies the same procedure but discards observations in blocks where controls are absent, by searching the control unit from the block with the closest propensity score. When weighted, this procedure allows to match treated units only with controls with nearest neighbors with a propensity score falling in a predefined range. See Becker and Ichino (2002).
} 
The estimates presented in section 4 assume that we have a recursive model, and in particular that the residuals of the information gathering equation (2) are uncorrelated with those of the policy opinions equation (1). As explained in Wooldridge (2000), when dealing with binary endogenous variables the exogeneity assumption can be tested by means of a simple two-steps procedure. First we run a linear regression of equation (2) and save the residuals $\hat{u}_{\mathrm{i}}$. Next we estimate a probit model of $Y_{i}$ on $X_{i}, I_{i}$ and $\hat{u}_{i}$ and we use the t-statistics on $\hat{u}_{i}$ as a test of the null hypothesis that information is exogenous. Importantly this test is valid without assuming normality or homoskedasticity of $u_{i}$ and can be applied even if $I_{i}$ is a binary variable.

These t-statistics are displayed in Table 4. They all reject the exogeneity of information in the regression on policy opinions for all samples and measures of information. The estimated coefficient of $\hat{u}_{i}$ (the variable resid in Table 4) is always negative, which implies that the correlation between the error terms of (1) and (2) is also negative. This in turn suggests that the estimated coefficients of the information variables reported in Tables 2 and 3, under the exogeneity assumption, are likely to be biased downwards. In other words, these estimated coefficients provide a lower bound for the effect of information on the willingness to reform. We now turn to methods to deal with this endogeneity problem.

\section{(insert Table 4 about here)}

\subsection{Biprobit estimation}

Our first method to cope with the joint determination of information and policy opinions is to rely on functional form restrictions. In particular, we jointly estimate equations (1) and (2) by maximum likelihood methods, exploiting the fact that we can measure both policy opinions and information as binary variables. Identification is achieved through a functional form assumption: we assume that the error terms in (1) and (2) are jointly normally distributed, and that the equations $F($.$) and G($.$) are both$ linear.

To estimate with probit, we need to measure information as a binary variable. Thus, in the sample of employed individuals and of employees, we replace the comprehensive variables info2 and info3 with the binary variables info_payg and info_rate (each available for different subsamples of respondents). Rather than measuring the comprehensive impact of information, thus, these variables measure the effect of possessing specific bits of information. The correlogram of info_payg, info_rate, info2 and info3 always displays positive and statistically significant coefficients, except in the case of the correlation between info_rate and info2.

Table 5 reports the results. The information equation includes all the controls also included in the policy opinions equation, plus the variable noclue used as an instrument and thus excluded from the policy opinions equation (see the next subsection for a more extensive discussion of this variable). Once more, informed individuals are more likely 
to favor reforms, and the effect of information is statistically significant. The coefficients are larger and the standard deviations smaller compared to the simple probit regression and the propensity score matching estimators, a further confirmation that the estimates that assume exogeneity are biased downwards. Note that the estimated coefficient of the information variable is very similar in the three columns of Table 5, despite the different definitions of what information is about, and the different samples of respondents. This stability is a further sign of robustness.

(insert Table 5 about here )

\subsection{Instrumental variable estimation}

Despite the encouraging results reported in the previous subsection, the validity of the functional form restrictions reported in Table 5 remains open to doubt. Our second method to cope with the joint determination of information and policy opinions relies on an exclusion restriction. As already anticipated, as an instrument for information we use the variable noclue ${ }^{6}$, which reports the number of times the respondent answered don't know / no answer to 13 questions about the desirability of alternative broad policy issues and reform options (other than the two questions on retirement age and the generosity of pension benefits that were used to construct our dependent variable, shrink). Thus, this variable measures how strongly held are the respondent's opinions about other aspects of pension reforms: the higher the value of noclue, the less strongly held are his opinions. Again, this variable is neutral with respect to the desirability of reforms, and about whether they should take the form of higher contributions or of a less generous pension system. ${ }^{7}$

This variable is a valid instrument if it is uncorrelated with the error term of equation (1). In other words, our identifying assumption is that, after controlling for all the other individual attributes, this variable influences policy opinions only through its impact on information (as we measure it). The validity of this identifying assumption cannot be tested.

Panel 1 of Table 6 reports the first stage, where information is regressed on the full set of controls plus our instrument. We estimate a linear equation, to minimize the risk of specification error (Angrist and Krueger 2001). The variable noclue always has statistically significant estimated coefficients with the expected sign, in all samples and for all measures of information.

\section{(insert Table 6 about here)}

\footnotetext{
${ }^{6}$ We also tried as instruments other variables capturing the supply of information at the local level, such as the number of copies sold by economic newspapers in the different provinces, or the local turnout in national elections. None of these variables, however, turned out to be significantly correlated with information, as further discussed in section 6, perhaps because we could only draw on variation across provinces and our sample size (1,500 individuals) does not allow for small area representation.

Recall that, by definition, the dependent variable shrink does not allow for don't know / no answer to both options for pension reform; moreover, shrink is defined so that a don't know / no answer to one policy option only can be associated both with shrink equal one and to shrink equal zero.
} 
Panel 2 of Table 6 reports the second stage regression, also with a linear specification. Information has a positive and statistically significant effect in the willingness to accept reforms, confirming the results of the previous section. Note that, again, this applies to all definitions of information and to all samples of respondents (although here the estimated coefficients differ more across the three columns in Table 6). The estimated coefficients in Table 6 are not immediately comparable to those of Tables 2 and 5, because of the different functional form assumptions. They are more comparable with the matching estimates displayed in Table 3, and they turn out to be much larger here, possibly because of the exogeneity assumption made by propensity score estimators. This is confirmed by estimating the second stage by OLS with a linear specification as in Table 6, but assuming that information is exogenous: the OLS estimate of the coefficients for information are smaller than the 2SLS estimates reported in the bottom panel of Table 6. This confirms the previous remarks, that joint endogeneity of information and policy opinions creates a downward bias in the estimated effect of information on the willingness to reform.

\section{Involvement in public debate and information}

Overall, the estimates reported in the previous section are remarkably robust to the estimation method. They all confirm the presence of a significant effect of information on the willingness to accept pension reforms. But where does information come from, and how can its diffusion be increased? In this section we briefly address this issue. In particular, we ask whether more informed individuals have enjoyed a greater exposure to media coverage of pension issues.

In the months preceding the interviews, there was extensive media coverage of pension issues, as the government announced its intention to carry out a new reform of the Italian pension system (which was then approved by Parliament in July 2004). Two questions in the survey elicited the degree of involvement of respondents in this public debate. The first question asked: "during the last months did you read newspaper articles or watch TV programs concerning the pension reform debate?” - the variable involvement. A yes answer was reported by roughly two-thirds of respondents. The second question measured the degree of involvement, by classifying the level of attention to the debate in four categories (high, medium, low, none) - the variable attention. Almost half the respondents reported a high to medium level of attention and another 35\% a low level. Overall, these questions confirm a strong involvement of public opinion in the pension reform debate.

Table 7 reports probit and propensity score matching estimates of the effects of involvement and attention on information about the financing (info_deficit), the functioning (info_payg) and the individual cost (info_rate) of the pension system. Throughout we assume a recursive model, with the variables involvement and attention assumed to be exogenous in the information equation (i.e. uncorrelated with the unobserved determinants of individual information). The Probit regressions (reported in the top panel) included, in addition to involvement and coverage, the same covariates 
used in the first stage IV estimation discussed in section 5 above and a variable (press) capturing the number of copies sold by national newspapers per inhabitant in each province. The variables involvement and attention are never statististically significant, except for a mild role of attention when the focus is on the sample of employees and information refers to contributions paid (info_rate). Propensity score-matching estimates (confined to the effect of involvement on the info_deficit variable covering the full sample) also confirm that the estimated coefficients are not statistically significant see the lower panel of Table 7. Among the variables positively affecting info_deficit in the first-stage probit regression, we find expertinfl, which captures those willing to give a stronger role the experts in the pension reform debate. As this variable also positively affects the support to pension reforms (see Section 4), it is likely to capture beliefs (experts are often favorable to reforms dealing with the ageing of population) more than neutral demand for information on these issues.

\section{(insert Table 7 about here)}

Overall, these last estimates suggest that the public debate has a low informational content. Individuals that declare to be more exposed to media coverage do not appear to be more informed about basic features of the pension system. One interpretation of this result is that individuals read newspaper articles or watch TV programs on the issue just to confirm their priors, more than to collect new information. Alternatively, our coding of individual involvement ad attention to the media could be measured with error.

\section{Concluding remarks}

The main result of this paper is the finding that more informed individuals are more willing to accept reforms that reduce the generosity of the pension system. The correlation between information and willingness to reform does not seem to reflect unobserved joint determinants of information and policy opinions. A variety of estimation methods under alternative identifying assumptions suggests that information has a causal effect on willingness to reform. The effect is not negligible. Our lower bound estimates (those assuming exogeneity of information) indicate that, for a middleaged woman located at the centre of a political spectrum, the probability of supporting reforms increases by 8 percent when they are informed that the pension system is in deficit. When we allow for joint endogeneity of information and policy opinions, the effect is much larger than that.

This result has a simple but important policy implication. Pension reforms are politically very difficult. One reason why they are so difficult is also because of sheer ignorance by citizens at large about the costs, sustainability and basic functioning of the pension system. To create consensus in favor of reforms, governments ought to devote more effort to spread information about the consequences and costs of public pensions.

The negative results about the effect of media exposure on information suggest that this task cannot just be delegated to the media, however. Governments ought to find better and more direct ways of spreading information. One such device would be for 
governments to provide "pension statements" reporting to contributors their current entitlements. In most European countries with unreformed pension systems - including France, Germany, Italy and Spain -- it is still extremely cumbersome to know the amount of individual contributions and to project future pension entitlements under a standard career profile and alternative retirement ages. In Sweden, by contrast, “orange envelopes" are mailed every year to all contributors, providing basic information on the functioning of the pension system, a glossary, a statement of past contributions and projections of the annual entitlements under three retirement ages and for two assumptions on economic growth. ${ }^{8}$ Our results suggest that this practice could have beneficial effects. If the large countries of continental Europe were to follow the Swedish example, and if this indeed enabled citizens to become more informed about the features of their pension systems, the political feasibility of pension reforms could rise significantly.

\footnotetext{
${ }^{8}$ According to a survey carried out in 2003 among a representative sample of contributors to the Swedish pension system (Sundén, 2003), almost everybody was aware of the envelope and about 2/3 of contributors opened and read at least part of the material. Among the latter group, almost 7 out of 10 looked at the benefit projection and 1 out of 4 compared the information in the orange envelope from one year to the next.
} 
Table 1. Summary statistics

\begin{tabular}{lcccccc}
\hline Variable & Obs & Mean & Std. Dev. & Min & Max & Median \\
\hline \hline shrink & 1443 & 0.376 & 0.484 & 0 & 1 & 0 \\
info_deficit & 1500 & 0.655 & 0.475 & 0 & 1 & 1 \\
info_payg & 779 & 0.524 & 0.500 & 0 & 1 & 1 \\
info_rate & 627 & 0.268 & 0.443 & 0 & 1 & 0 \\
info2 & 779 & 1.240 & 0.719 & 0 & 2 & 1 \\
info3 & 627 & 1.496 & 0.843 & 0 & 3 & 2 \\
\hline male & 1500 & 0.469 & 0.499 & 0 & 1 & 0 \\
married & 1500 & 0.722 & 0.448 & 0 & 1 & 1 \\
old & 1500 & 0.31 & 0.463 & 0 & 1 & 0 \\
young & 1500 & 0.219 & 0.413 & 0 & 1 & 0 \\
university & 1500 & 0.154 & 0.361 & 0 & 1 & 0 \\
compulsory & 1500 & 0.386 & 0.487 & 0 & 1 & 0 \\
children & 1500 & 0.287 & 0.452 & 0 & 1 & 0 \\
pensioner & 1500 & 0.224 & 0.417 & 0 & 1 & 0 \\
town & 1500 & 0.531 & 0.499 & 0 & 1 & 1 \\
city & 1500 & 0.257 & 0.437 & 0 & 1 & 0 \\
whitecollar & 1500 & 0.235 & 0.424 & 0 & 1 & 0 \\
bluecollar & 1500 & 0.117 & 0.322 & 0 & 1 & 0 \\
headpens & 1500 & 0.366 & 0.482 & 0 & 1 & 0 \\
planearly & 1500 & 0.134 & 0.341 & 0 & 1 & 0 \\
dini & 1500 & 0.493 & 0.500 & 0 & 1 & 0 \\
id_left & 1500 & 0.173 & 0.379 & 0 & 1 & 0 \\
id_right & 1500 & 0.162 & 0.369 & 0 & 1 & 0 \\
crisis & 1500 & 0.641 & 0.480 & 0 & 1 & 1 \\
involvement & 1500 & 0.712 & 0.453 & 0 & 1 & 1 \\
attention & 1500 & 2.623 & 0.898 & 1 & 4 & 3 \\
expertinfl & 1500 & 0.316 & 0.465 & 0 & 1 & 0 \\
unioninfl & 1500 & 0.515 & 0.499 & 0 & 1 & 1 \\
tradeunion & 0.278 & 0.448 & 0 & 1 & 0 \\
noclue & 2.004 & 2.208 & 0 & 13 & 1 \\
\hline \hline & & & & & & \\
\hline
\end{tabular}


Table 2. Probit regression

\begin{tabular}{|c|c|c|c|}
\hline & $\begin{array}{c}(1) \\
\text { Shrink }\end{array}$ & $\begin{array}{c}(2) \\
\text { shrink }\end{array}$ & $\begin{array}{c}\text { (3) } \\
\text { shrink }\end{array}$ \\
\hline male & $\begin{array}{c}0.30 \\
(0.07)^{\star \star \star}\end{array}$ & $\begin{array}{c}0.27 \\
(0.10)^{\star \star \star}\end{array}$ & $\begin{array}{c}0.13 \\
(0.12)\end{array}$ \\
\hline married & $\begin{array}{l}-0.13 \\
(0.10)\end{array}$ & $\begin{array}{c}-0.22 \\
(0.13)\end{array}$ & $\begin{array}{c}-0.27 \\
(0.15)^{\star}\end{array}$ \\
\hline children & $\begin{array}{l}-0.15 \\
(0.09)\end{array}$ & $\begin{array}{l}-0.11 \\
(0.12)\end{array}$ & $\begin{array}{l}-0.06 \\
(0.14)\end{array}$ \\
\hline young & $\begin{array}{c}0.03 \\
(0.10)\end{array}$ & $\begin{array}{c}0.11 \\
(0.14)\end{array}$ & $\begin{array}{c}0.11 \\
(0.16)\end{array}$ \\
\hline old & $\begin{array}{l}-0.13 \\
(0.13)\end{array}$ & $\begin{array}{l}-0.21 \\
(0.19)\end{array}$ & $\begin{array}{l}-0.04 \\
(0.21)\end{array}$ \\
\hline university & $\begin{array}{c}0.18 \\
(0.10)^{\star}\end{array}$ & $\begin{array}{c}0.11 \\
(0.13)\end{array}$ & $\begin{array}{c}0.19 \\
(0.15)\end{array}$ \\
\hline compulsory & $\begin{array}{c}0.02 \\
(0.08)\end{array}$ & $\begin{array}{c}0.08 \\
(0.13)\end{array}$ & $\begin{array}{c}0.01 \\
(0.14)\end{array}$ \\
\hline pensioner & $\begin{array}{c}0.16 \\
(0.14)\end{array}$ & & \\
\hline whitecollar & $\begin{array}{c}-0.31 \\
(0.09)^{\star \star \star}\end{array}$ & $\begin{array}{c}-0.46 \\
(0.12)^{\star \star \star}\end{array}$ & $\begin{array}{l}-0.15 \\
(0.12)\end{array}$ \\
\hline bluecollar & $\begin{array}{c}-0.31 \\
(0.12)^{\star \star}\end{array}$ & $\begin{array}{c}-0.48 \\
(0.15)^{\star \star \star}\end{array}$ & \\
\hline capopens & $\begin{array}{c}0.01 \\
(0.10)\end{array}$ & $\begin{array}{c}0.13 \\
(0.15)\end{array}$ & $\begin{array}{c}0.02 \\
(0.16)\end{array}$ \\
\hline planearly & $\begin{array}{l}-0.16 \\
(0.11)\end{array}$ & $\begin{array}{l}-0.19 \\
(0.13)\end{array}$ & $\begin{array}{l}-0.15 \\
(0.14)\end{array}$ \\
\hline dini & $\begin{array}{l}-0.02 \\
(0.08)\end{array}$ & $\begin{array}{l}-0.13 \\
(0.14)\end{array}$ & $\begin{array}{l}-0.16 \\
(0.15)\end{array}$ \\
\hline id_left & $\begin{array}{l}-0.11 \\
(0.10)\end{array}$ & $\begin{array}{c}0.00 \\
(0.13)\end{array}$ & $\begin{array}{l}-0.03 \\
(0.14)\end{array}$ \\
\hline id_right & $\begin{array}{c}0.40 \\
(0.10)^{\star \star \star}\end{array}$ & $\begin{array}{c}0.57 \\
(0.13)^{\star \star \star}\end{array}$ & $\begin{array}{c}0.64 \\
(0.15)^{\star \star \star}\end{array}$ \\
\hline crisis & $\begin{array}{c}0.10 \\
(0.07)\end{array}$ & $\begin{array}{c}0.11 \\
(0.11)\end{array}$ & $\begin{array}{c}0.07 \\
(0.12)\end{array}$ \\
\hline tradeunion & $\begin{array}{c}0.10 \\
(0.08)\end{array}$ & $\begin{array}{l}0.17 \\
(0.11)\end{array}$ & $\begin{array}{c}0.21 \\
(0.12)^{\star}\end{array}$ \\
\hline unioninfl & $\begin{array}{c}-0.27 \\
(0.07)^{\star \star \star}\end{array}$ & $\begin{array}{c}-0.35 \\
(0.10)^{\star \star \star}\end{array}$ & $\begin{array}{c}-0.30 \\
(0.11)^{\star \star \star}\end{array}$ \\
\hline expertinfl & $\begin{array}{c}0.20 \\
(0.08)^{\star \star \star}\end{array}$ & $\begin{array}{c}0.27 \\
(0.11)^{\star \star}\end{array}$ & $\begin{array}{c}0.29 \\
(0.12)^{\star \star}\end{array}$ \\
\hline info_deficit & $\begin{array}{c}0.21 \\
(0.08)^{\star \star \star} \\
0.08^{\mathrm{a}}\end{array}$ & & \\
\hline info2 & & $\begin{array}{c}0.16 \\
(0.07)^{\star \star} \\
0.06^{\mathrm{a}}\end{array}$ & \\
\hline info3 & & & $\begin{array}{c}0.12 \\
(0.07)^{\star} \\
0.04^{\circ}\end{array}$ \\
\hline $\begin{array}{l}\text { Observations } \\
\text { Pseudo R2 }\end{array}$ & $\begin{array}{l}1443 \\
0.06\end{array}$ & $\begin{array}{l}755 \\
0.10\end{array}$ & $\begin{array}{l}606 \\
0.07\end{array}$ \\
\hline
\end{tabular}

Notes: Standard errors in parentheses; * significant at $10 \%$; ** significant at $5 \%$; *** significant at $1 \%$; ${ }^{a}$ marginal effect on reference group (dprobit estimation). 
Table 3 Propensity score matching

\begin{tabular}{ccccc}
\hline \hline Outcome & Treatment & $\begin{array}{c}\text { Propensity score matching } \\
\text { methods }\end{array}$ & Coeff & t test \\
\hline & & $\begin{array}{c}\text { - Nearest neighbor matching } \\
\text { method (random draw version) }\end{array}$ & $\begin{array}{c}0.075 \\
(0.039)\end{array}$ & $\mathrm{t}=1.942$ \\
shrink & info_deficit & $\begin{array}{c}\text { - Nearest neighbor matching } \\
\text { method (equal weights version) }\end{array}$ & $\begin{array}{c}0.077 \\
(0.038)\end{array}$ & $\mathrm{t}=2.019$ \\
& & - Stratification method & $\begin{array}{c}0.082 \\
(\text { sample: all) }\end{array}$ & $\mathrm{t}=3.182$ \\
& & \\
\hline \hline
\end{tabular}

Note: Standard errors in parentheses

Table 4 Exogeneity test

\begin{tabular}{|c|c|c|c|}
\hline & $\begin{array}{c}\text { All } \\
(1) \\
\text { Shrink }\end{array}$ & $\begin{array}{c}\text { Employed } \\
(2) \\
\text { shrink }\end{array}$ & $\begin{array}{c}\text { Employees } \\
\text { (3) } \\
\text { Shrink }\end{array}$ \\
\hline info_deficit & $\begin{array}{c}5.00 \\
(1.32)^{\star \star \star}\end{array}$ & & \\
\hline info2 & & $\begin{array}{c}3.59 \\
(0.91)^{\star \star \star}\end{array}$ & \\
\hline info3 & & & $\begin{array}{c}2.99 \\
(0.71)^{\star \star \star}\end{array}$ \\
\hline resid & $\begin{array}{c}-4.80 \\
(1.32)^{\star \star \star}\end{array}$ & $\begin{array}{c}-3.46 \\
(0.91)^{\star \star \star}\end{array}$ & $\begin{array}{c}-2.90 \\
(0.72)^{\star \star \star}\end{array}$ \\
\hline Observations & 1443 & 755 & 606 \\
\hline Pseudo R2 & 0.07 & 0.11 & 0.09 \\
\hline
\end{tabular}


Table 5. Maximum likelihood joint-probit estimation

\begin{tabular}{|c|c|c|c|}
\hline & $\begin{array}{c}\text { All } \\
(1) \\
\text { info_deficit }\end{array}$ & $\begin{array}{c}\text { Employed } \\
\text { (2) } \\
\text { info_payg }\end{array}$ & $\begin{array}{c}\text { Employees } \\
\text { (3) } \\
\text { info_rate }\end{array}$ \\
\hline \multirow[t]{2}{*}{ noclue } & -0.05 & -0.08 & -0.11 \\
\hline & $(0.02)^{\star \star \star}$ & $(0.02)^{\star \star \star}$ & $(0.03)^{\star \star \star}$ \\
\hline \multirow[t]{2}{*}{ Observations } & 1443 & 755 & 606 \\
\hline & $\begin{array}{c}\text { All } \\
(1) \\
\text { Shrink }\end{array}$ & $\begin{array}{c}\text { Employed } \\
\text { (2) } \\
\text { shrink }\end{array}$ & $\begin{array}{c}\text { Employees } \\
\text { (3) } \\
\text { shrink }\end{array}$ \\
\hline info_deficit & $\begin{array}{c}1.50 \\
(0.12)^{\star \star \star}\end{array}$ & & \\
\hline info_payg & & $\begin{array}{c}1.50 \\
(0.09)^{\star \star \star}\end{array}$ & \\
\hline info_rate & & & $\begin{array}{c}1.65 \\
(0.11)^{\star \star \star}\end{array}$ \\
\hline Observations & 1443 & 755 & 606 \\
\hline
\end{tabular}

Notes: Standard errors in parentheses; * significant at 10\%; ** significant at 5\%; ${ }^{\star * *}$ significant at $1 \%$; Not reported variables: male, married, old, young, university, compulsory, children, pensioner (only for sample one), town, city, whitecollar, bluecollar (only for saple one and two), headpens, planearly, dini, id_left, id_right, crisis, tradeunion, unioninfl, expertinfl 
Table 6 Instrumental variables, linear regressions

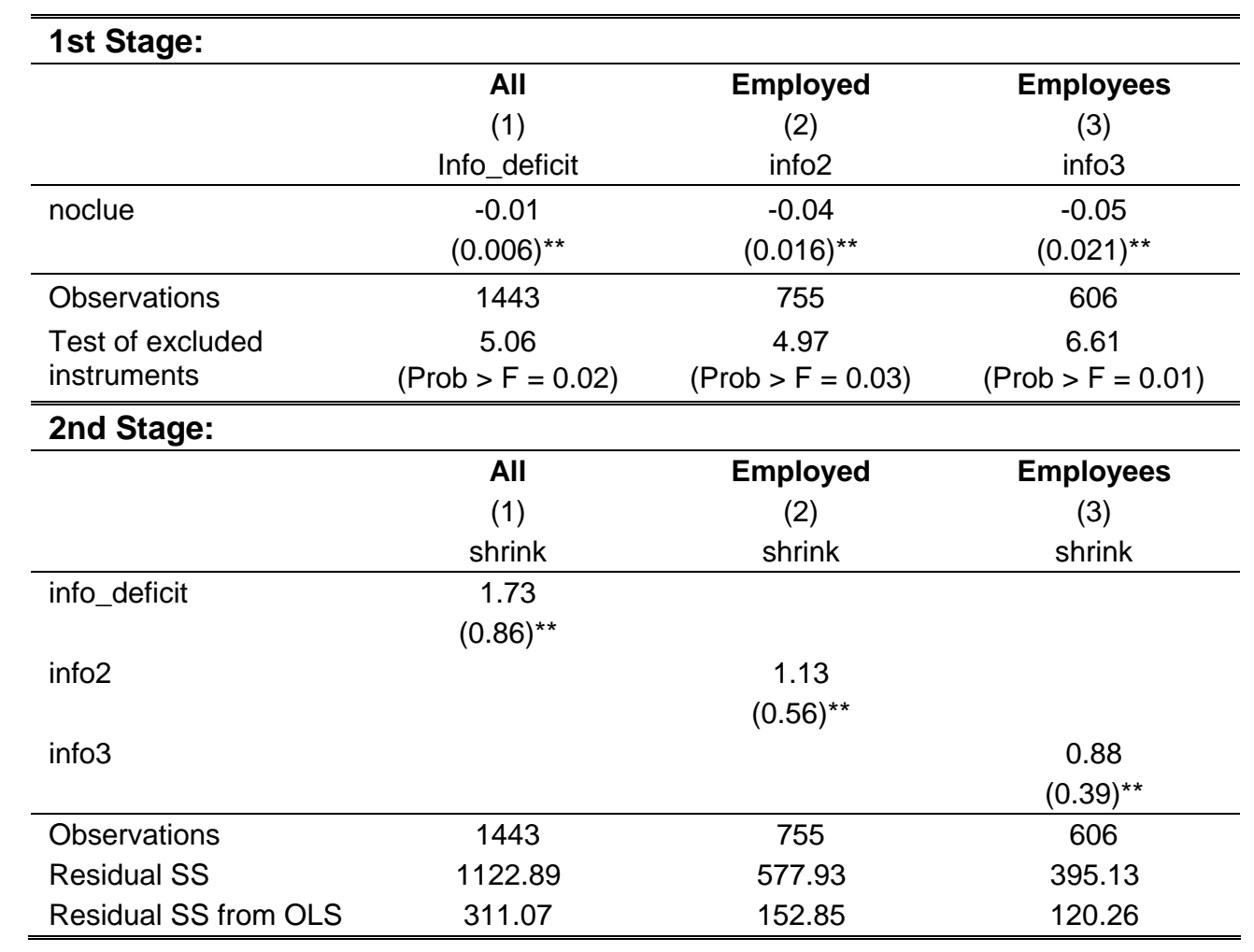

Notes: $\quad$ Standard errors in parentheses; * significant at 10\%; ${ }^{* *}$ significant at 5\%; ${ }^{\star * \star}$ significant at $1 \%$; Not reported variables: male, married, old, young, university, compulsory, children, pensioner (only forsample one), whitecollar, bluecollar (only for sample one and two), headpens, planearly, dini, id_left, id_right, crisis, tradeunion, unioninfl, expertinfl. 


\section{Table 7}

\section{Involvement in the public debate and information}

\begin{tabular}{|c|c|c|c|}
\hline & \multicolumn{3}{|c|}{ Dependent variables } \\
\hline & $\begin{array}{l}\text { info_deficit } \\
\text { (sample: all) }\end{array}$ & $\begin{array}{l}\text { info_payg } \\
\text { (sample: } \\
\text { employed) }\end{array}$ & $\begin{array}{l}\text { info_rate } \\
\text { (sample: } \\
\text { employees) }\end{array}$ \\
\hline \multicolumn{4}{|l|}{ Probit estimations: } \\
\hline \multirow[t]{2}{*}{ attention } & 0.04 & 0.00 & 0.16 \\
\hline & $(0.05)$ & $(0.06)$ & $(0.08)^{\star \star}$ \\
\hline \multirow[t]{2}{*}{ involvement } & 0.02 & 0.16 & 0.08 \\
\hline & $(0.09)$ & $(0.12)$ & $(0.16)$ \\
\hline \multirow[t]{2}{*}{ press } & 0.74 & 2.34 & -0.49 \\
\hline & $(1.10)$ & $(1.48)$ & $(1.82)$ \\
\hline Observations & 1500 & 779 & 627 \\
\hline \multirow[t]{3}{*}{ Pseudo R2 } & 0.06 & 0.02 & 0.07 \\
\hline & \multicolumn{3}{|c|}{ Outcome: info_deficit (sample: all) } \\
\hline & Coefficient & & $\mathrm{t}$ test \\
\hline \multirow{2}{*}{\multicolumn{4}{|c|}{$\begin{array}{l}\text { Propensity score matching: } \\
\text { involvement (treatment): }\end{array}$}} \\
\hline & & & \\
\hline $\begin{array}{l}\text { - Nearest Neighbor Matching } \\
\text { method (random draw version) }\end{array}$ & \multicolumn{2}{|l|}{$\begin{array}{l}-0.007 \\
(0.039)\end{array}$} & $t=-0.168$ \\
\hline $\begin{array}{l}\text { - Nearest Neighbor Matching } \\
\text { method (equal weights version) }\end{array}$ & \multicolumn{2}{|l|}{$\begin{array}{l}-0.006 \\
(0.039)\end{array}$} & $t=-0.160$ \\
\hline - Statification method & $\begin{array}{c}0.030 \\
(0.027) \\
\end{array}$ & & $t=1.083$ \\
\hline
\end{tabular}

Notes: Standard errors in parentheses; * significant at 10\%; ** significant at 5\%; ${ }^{\star \star *}$ significant at $1 \%$ 
Figure 1

Propensity scores for the treated and controls
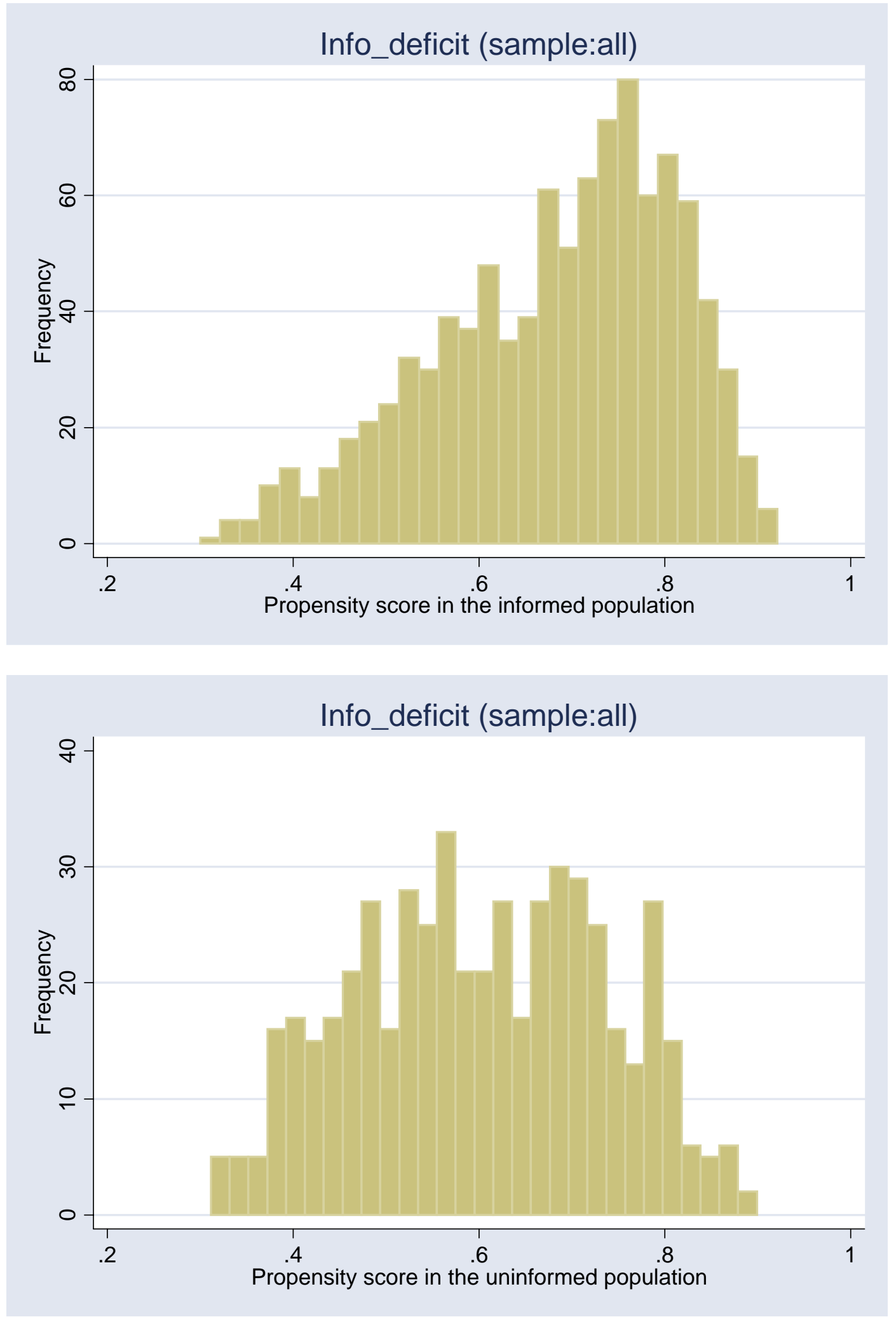


\section{References}

Blinder, A.S. and Krueger, A.B. (2004), "What Does the Public Know about Economic Policy and How Does It Know It?”, Brooking Papers on Economic Activity, 1:2004, pp327-397.

Boeri, T., Boersch-Supan, A. and Tabellini, G. (2002), "Pension Reforms and the Opinion of European Citizens", American Economic Association Papers and Proceedings, Vol. 92(2), pp. 396-401.

Boeri, T., Boersch-Supan, A. and Tabellini, G. (2001), "Would You Like to Shrink the Welfare State? The Opinions of European Citizens”, Economic Policy, Vol. 32, pp. 950 .

Jappelli T., Padula, A. and Bottazzi, R. (2003) "Retirement Expectations and Pension Reforms," CSEF Working Papers 92, Centre for Studies in Economics and Finance (CSEF), University of Salerno, Italy.

Sundén, A. (2003), "How Much People Need to Know about Their Pensions and What do They Know?”, mimeo. 


\begin{abstract}
Annex 1
As explained in section 3, our dependent variable shrink is missing for the 57 individuals (out of 1500) that answered don't / no answer to both questions (on retirement age and on pension benefits). A more restrictive definition of shrink, excluding those individuals who answered don't / no answer to either the question on retirement age or that on pension benefits is missing for 210 individuals. This annex reports alternative estimates, to make sure that non-random censoring is not a cause of selection bias.
\end{abstract}

As a first check, we have re-estimated equation (1) with the dichotomous variable shrink as our dependent variable, treating information as exogenous, but with the twostep Heckman procedure that allows for non-random censoring of observations. The results are displayed in Tables A.1 and A.2, for the same specification as in Table 2 in the text. Table A1 refers to the definition of shrink used throughout the paper, where missing observations correspond to those that answered don't know / no answer to both reform options. Table A2 refers to the alternative definition of shrink, where someone who answers don't know /no answer to either reform option is treated as missing. The estimated coefficients of information in the second stage regression remain statistically significant in all samples and definitions of shrink, except among the employees only, although they are smaller than in the logit regression of Table 2. This reassures us that the omission of these few agnostic individuals does not create a relevant selection bias.

As a second robustness check, we have redefined the dependent variable shrink to also include as a third separate value the individuals who answer don't know / no answer to both policy questions. Table A.3 displays multinomial logit estimates (i.e., responses are not ordered in any hierarchy). The comparison group is always those who oppose at least one reform (and do not strictly approve the other reform). Column (1) refers to those who are in favour of at least one reform (relative to the comparison group). Column 2 refers to those who answer don't know /no answer to both questions (relative to the same comparison group). The sample consists of all respondents. Columns 3-4 and 5-6 repeat the same estimation for the sample of employed individuals and employees respectively.

The last three rows report the estimated coefficients of interest on the variables measuring information, namely info_deficit, info2 and info3. The rows reporting the estimated coefficients of the other controls are omitted. The estimated coefficients on the information variables are statistically significant and similar in value to those estimated on the binary definition of shrink and reported in Table 2 in the text. 
Table A1. Implications of omitting DN/NA answers to both reform options

\begin{tabular}{|c|c|c|c|}
\hline \multicolumn{4}{|l|}{$1^{\text {st }}$ Stage: } \\
\hline & $\begin{array}{c}\text { All } \\
(1) \\
\text { dontknow }\end{array}$ & $\begin{array}{c}\text { Employed } \\
(2) \\
\text { dontknow }\end{array}$ & $\begin{array}{c}\text { Employees } \\
(3) \\
\text { dontknow }\end{array}$ \\
\hline Male & $\begin{array}{c}0.09 \\
(0.14)\end{array}$ & $\begin{array}{c}0.06 \\
(0.20)\end{array}$ & $\begin{array}{c}0.19 \\
(0.24)\end{array}$ \\
\hline Married & $\begin{array}{c}0.01 \\
(0.19)\end{array}$ & $\begin{array}{c}0.18 \\
(0.26)\end{array}$ & $\begin{array}{c}0.24 \\
(0.29)\end{array}$ \\
\hline Old & $\begin{array}{c}0.15 \\
(0.22)\end{array}$ & $\begin{array}{c}0.00 \\
(0.38)\end{array}$ & $\begin{array}{c}0.39 \\
(0.48)\end{array}$ \\
\hline Young & $\begin{array}{c}0.24 \\
(0.22)\end{array}$ & $\begin{array}{c}0.06 \\
(0.29)\end{array}$ & $\begin{array}{l}-0.01 \\
(0.28)\end{array}$ \\
\hline university & $\begin{array}{c}0.07 \\
(0.23)\end{array}$ & $\begin{array}{c}0.07 \\
(0.32)\end{array}$ & $\begin{array}{l}-0.00 \\
(0.35)\end{array}$ \\
\hline compulsory & $\begin{array}{l}-0.06 \\
(0.15)\end{array}$ & $\begin{array}{l}-0.24 \\
(0.27)\end{array}$ & $\begin{array}{l}-0.22 \\
(0.29)\end{array}$ \\
\hline children & $\begin{array}{l}0.05 \\
(0.17)\end{array}$ & $\begin{array}{l}-0.04 \\
(0.24)\end{array}$ & $\begin{array}{l}-0.02 \\
(0.26)\end{array}$ \\
\hline pensioner & $\begin{array}{l}-0.10 \\
(0.24)\end{array}$ & & \\
\hline whitecollar & $\begin{array}{l}-0.14 \\
(0.19)\end{array}$ & $\begin{array}{l}-0.05 \\
(0.26)\end{array}$ & $\begin{array}{c}0.12 \\
(0.24)\end{array}$ \\
\hline bluecollar & $\begin{array}{c}-0.40 \\
(0.21)^{\star}\end{array}$ & $\begin{array}{l}-0.17 \\
(0.30)\end{array}$ & \\
\hline capopens & $\begin{array}{l}-0.14 \\
(0.18)\end{array}$ & & $\begin{array}{l}-0.01 \\
(0.28)\end{array}$ \\
\hline planearly & $\begin{array}{c}0.29 \\
(0.24)\end{array}$ & & $\begin{array}{c}0.04 \\
(0.28)\end{array}$ \\
\hline Dini & $\begin{array}{l}-0.12 \\
(0.15)\end{array}$ & $\begin{array}{l}-0.04 \\
(0.28)\end{array}$ & $\begin{array}{c}0.13 \\
(0.32)\end{array}$ \\
\hline id_left & $\begin{array}{c}0.28 \\
(0.20)\end{array}$ & $\begin{array}{l}-0.06 \\
(0.27)\end{array}$ & $\begin{array}{c}0.37 \\
(0.37)\end{array}$ \\
\hline id_right & $\begin{array}{l}-0.11 \\
(0.19)\end{array}$ & $\begin{array}{l}-0.00 \\
(0.30)\end{array}$ & $\begin{array}{l}-0.13 \\
(0.33)\end{array}$ \\
\hline Crisis & & $\begin{array}{l}-0.33 \\
(0.24)\end{array}$ & $\begin{array}{l}-0.12 \\
(0.27)\end{array}$ \\
\hline tradeunion & $\begin{array}{l}-0.09 \\
(0.15)\end{array}$ & $\begin{array}{l}-0.11 \\
(0.22)\end{array}$ & $\begin{array}{l}-0.09 \\
(0.22)\end{array}$ \\
\hline unioninfl & $\begin{array}{l}-0.13 \\
(0.14)\end{array}$ & $\begin{array}{l}-0.20 \\
(0.22)\end{array}$ & $\begin{array}{l}-0.25 \\
(0.24)\end{array}$ \\
\hline expertinfl & $\begin{array}{c}0.06 \\
(0.17)\end{array}$ & $\begin{array}{l}-0.13 \\
(0.23)\end{array}$ & $\begin{array}{l}-0.23 \\
(0.25)\end{array}$ \\
\hline Noclue & $\begin{array}{c}-0.17 \\
(0.03)^{\star \star \star}\end{array}$ & $\begin{array}{c}-0.24 \\
(0.05)^{\star \star \star}\end{array}$ & $\begin{array}{c}-0.28 \\
(0.05)^{\star \star \star}\end{array}$ \\
\hline Observations & 1500 & 779 & 627 \\
\hline Censored obs & 57 & 24 & 21 \\
\hline \multicolumn{4}{|l|}{$2^{\text {nd }}$ Stage: } \\
\hline & $\begin{array}{c}\text { All } \\
(1) \\
\text { shrink } \\
\end{array}$ & $\begin{array}{c}\text { Employed } \\
(2) \\
\text { shrink } \\
\end{array}$ & $\begin{array}{c}\text { Employees } \\
(3) \\
\text { shrink } \\
\end{array}$ \\
\hline info_deficit & $\begin{array}{c}0.19 \\
(0.07)^{\star \star \star}\end{array}$ & & \\
\hline info2 & & $\begin{array}{c}0.13 \\
(0.07)^{\star \star}\end{array}$ & \\
\hline Info & & & $\begin{array}{c}0.09 \\
(0.06)\end{array}$ \\
\hline Observations & 1500 & 779 & 627 \\
\hline Uncensored obs & 1443 & 755 & 606 \\
\hline
\end{tabular}

Notes: Standard errors in parentheses; * significant at $10 \%$; ${ }^{*}$ significant at $5 \%$; ${ }^{* *}$ significant at $1 \%$. 
Table A2. Implications of omitting DN/NA answers to either increasing retirement age or reduce benefit options

\begin{tabular}{|c|c|c|}
\hline $1^{\text {st }}$ Stage: & & \\
\hline & $\begin{array}{c}\text { All } \\
(1) \\
\text { dontknow }\end{array}$ & $\begin{array}{c}\text { Employed } \\
(2) \\
\text { dontknow }\end{array}$ \\
\hline \multirow[t]{2}{*}{ male } & 0.11 & 0.06 \\
\hline & $(0.15)$ & $(0.21)$ \\
\hline married & $\begin{array}{c}0.04 \\
(0.20)\end{array}$ & $\begin{array}{l}0.15 \\
(0.26)\end{array}$ \\
\hline old & $\begin{array}{c}0.13 \\
(0.23)\end{array}$ & $\begin{array}{l}(0.20) \\
-0.01 \\
(0.39)\end{array}$ \\
\hline young & $\begin{array}{c}0.27 \\
(0.23)\end{array}$ & $\begin{array}{c}0.02 \\
(0.30)\end{array}$ \\
\hline university & $\begin{array}{c}0.05 \\
(0.24)\end{array}$ & $\begin{array}{c}0.07 \\
(0.33)\end{array}$ \\
\hline compulsory & $\begin{array}{l}-0.06 \\
(0.16)\end{array}$ & $\begin{array}{l}-0.29 \\
(0.29)\end{array}$ \\
\hline children & $\begin{array}{c}0.03 \\
(0.18)\end{array}$ & $\begin{array}{l}-0.03 \\
(0.24)\end{array}$ \\
\hline pensioner & $\begin{array}{l}-0.17 \\
(0.25)\end{array}$ & \\
\hline whitecollar & $\begin{array}{l}-0.14 \\
(0.20)\end{array}$ & $\begin{array}{l}-0.05 \\
(0.27)\end{array}$ \\
\hline bluecollar & $\begin{array}{l}-0.41 \\
(0.22)^{*}\end{array}$ & $\begin{array}{l}-0.13 \\
(0.32)\end{array}$ \\
\hline capopens & $\begin{array}{l}-0.14 \\
(0.18)\end{array}$ & \\
\hline planearly & $\begin{array}{c}0.24 \\
(0.25)\end{array}$ & \\
\hline dini & $\begin{array}{l}-0.09 \\
(0.15)\end{array}$ & $\begin{array}{l}-0.02 \\
(0.29)\end{array}$ \\
\hline id_left & $\begin{array}{c}0.34 \\
(0.21)\end{array}$ & $\begin{array}{l}-0.04 \\
(0.28)\end{array}$ \\
\hline id_right & $\begin{array}{l}-0.11 \\
(0.19)\end{array}$ & $\begin{array}{c}0.02 \\
(0.31)\end{array}$ \\
\hline crisis & & $\begin{array}{l}-0.34 \\
(0.25)\end{array}$ \\
\hline tradeunion & $\begin{array}{l}-0.09 \\
(0.16)\end{array}$ & $\begin{array}{l}-0.11 \\
(0.22)\end{array}$ \\
\hline unioninfl & $\begin{array}{l}-0.12 \\
(0.15)\end{array}$ & $\begin{array}{l}-0.15 \\
(0.22)\end{array}$ \\
\hline expertinfl & $\begin{array}{c}0.03 \\
(0.17)\end{array}$ & $\begin{array}{l}-0.15 \\
(0.24)\end{array}$ \\
\hline noclue & $\begin{array}{c}-0.19 \\
0.03^{\star \star \star}\end{array}$ & $\begin{array}{c}-0.25 \\
(0.05)^{\star \star \star}\end{array}$ \\
\hline Observation & 1290 & 691 \\
\hline Censored obs & 57 & 24 \\
\hline \multicolumn{3}{|l|}{$2^{\text {nd }}$ Stage: } \\
\hline & $\begin{array}{c}\text { All } \\
(1) \\
\text { shrink }^{a}\end{array}$ & $\begin{array}{c}\text { Employed } \\
(2) \\
\text { shrink }^{\mathrm{a}} \\
\end{array}$ \\
\hline Infodeficit_dummy & $\begin{array}{c}0.16 \\
(0.08)^{\star \star}\end{array}$ & \\
\hline info2 & & $\begin{array}{c}0.12 \\
(0.07)^{\star}\end{array}$ \\
\hline Observations & 1290 & 691 \\
\hline Uncensored obs & 1233 & 667 \\
\hline
\end{tabular}

Notes: Standard errors in parentheses; * significant at $10 \%$; ** significant at $5 \%$; ** significant at $1 \%{ }^{\text {(a) }}$ Shrink here is defined omitting don't know/no answer to either reducing pension benefits or increasing retirement age. 
Table A.3 Multinomial logit

\begin{tabular}{|c|c|c|c|c|c|c|}
\hline \multicolumn{7}{|c|}{$\begin{array}{l}\text { Dependent variable: shrink } \\
\text { Comparison group: against }\end{array}$} \\
\hline & \multicolumn{2}{|c|}{ All } & \multicolumn{2}{|c|}{ Employed } & \multicolumn{2}{|c|}{ Employees } \\
\hline & (1) & (2) & (3) & (4) & (5) & (6) \\
\hline & in favour & don't know & in favour & don't know & in favour & don't know \\
\hline \multirow[t]{2}{*}{ male } & -0.50 & -0.94 & -0.45 & -0.67 & -0.21 & -0.64 \\
\hline & $(0.12)^{\star \star \star}$ & $(0.32)^{\star \star \star}$ & $(0.17)^{\star \star \star}$ & $(0.46)$ & (0.19) & $(0.51)$ \\
\hline \multirow[t]{2}{*}{ married } & 0.23 & 0.14 & 0.43 & -0.19 & 0.51 & -0.21 \\
\hline & $(0.16)$ & $(0.42)$ & $(0.22)^{\star}$ & $(0.58)$ & $(0.25)^{\star \star}$ & $(0.61)$ \\
\hline \multirow[t]{2}{*}{ young } & -0.03 & -0.49 & -0.13 & -0.48 & -0.10 & -0.13 \\
\hline & $(0.17)$ & $(0.47)$ & $(0.24)$ & (0.65) & $(0.26)$ & $(0.72)$ \\
\hline \multirow[t]{2}{*}{ old } & 0.24 & -0.26 & 0.29 & 0.05 & 0.01 & -1.09 \\
\hline & $(0.21)$ & $(0.50)$ & $(0.31)$ & $(0.87)$ & $(0.35)$ & (1.13) \\
\hline \multirow[t]{2}{*}{ university } & -0.34 & -0.62 & -0.25 & -0.73 & -0.39 & -0.53 \\
\hline & $(0.16)^{\star \star}$ & $(0.57)$ & $(0.21)$ & $(0.82)$ & $(0.24)$ & $(0.83)$ \\
\hline \multirow[t]{2}{*}{ compulsory } & -0.04 & 0.38 & -0.13 & 0.53 & -0.04 & 0.75 \\
\hline & $(0.13)$ & $(0.33)$ & $(0.21)$ & (0.53) & (0.23) & (0.54) \\
\hline \multirow[t]{2}{*}{ children } & 0.24 & -0.02 & 0.18 & 0.12 & 0.14 & -0.05 \\
\hline & $(0.15)$ & $(0.39)$ & $(0.20)$ & (0.55) & $(0.22)$ & $(0.60)$ \\
\hline \multirow[t]{2}{*}{ pensioner } & -0.31 & -0.11 & & & & \\
\hline & $(0.23)$ & $(0.53)$ & & & & \\
\hline \multirow[t]{2}{*}{ town } & -0.13 & -0.16 & -0.09 & -0.35 & 0.03 & -0.19 \\
\hline & $(0.15)$ & $(0.37)$ & $(0.21)$ & $(0.51)$ & $(0.23)$ & $(0.55)$ \\
\hline \multirow[t]{2}{*}{ city } & -0.29 & -0.33 & 0.01 & -1.50 & 0.15 & -1.10 \\
\hline & $(0.17)^{\star}$ & $(0.43)$ & $(0.24)$ & $(0.84)^{\star}$ & $(0.27)$ & $(0.87)$ \\
\hline \multirow[t]{2}{*}{ whitecollar } & 0.52 & 0.43 & 0.75 & 0.69 & 0.24 & -0.11 \\
\hline & $(0.15)^{\star \star \star}$ & $(0.44)$ & $(0.19)^{\star \star \star}$ & $(0.60)$ & $(0.19)$ & $(0.50)$ \\
\hline \multirow[t]{2}{*}{ bluecollar } & 0.48 & 1.09 & 0.78 & 1.19 & & \\
\hline & $(0.20)^{\star \star}$ & $(0.45)^{\star \star}$ & $(0.24)^{\star \star \star}$ & $(0.64)^{\star}$ & & \\
\hline \multirow[t]{2}{*}{ capopens } & 0.04 & 0.53 & -0.13 & 0.04 & 0.10 & 0.18 \\
\hline & (0.16) & $(0.38)$ & $(0.24)$ & $(0.59)$ & $(0.27)$ & $(0.61)$ \\
\hline \multirow[t]{2}{*}{ planearly } & 0.29 & -0.58 & 0.33 & -0.32 & 0.26 & -0.22 \\
\hline & $(0.18)$ & $(0.57)$ & $(0.21)$ & $(0.60)$ & $(0.23)$ & $(0.62)$ \\
\hline \multirow[t]{2}{*}{ dini } & -0.01 & 0.12 & 0.16 & 0.08 & 0.22 & -0.25 \\
\hline & (0.13) & $(0.32)$ & $(0.22)$ & $(0.60)$ & $(0.25)$ & (0.65) \\
\hline \multirow[t]{2}{*}{ id_left } & 0.27 & -0.47 & 0.08 & -0.21 & 0.09 & -0.90 \\
\hline & $(0.16)^{\star}$ & $(0.47)$ & $(0.22)$ & $(0.61)$ & $(0.24)$ & $(0.79)$ \\
\hline \multirow[t]{2}{*}{ id_right } & -0.69 & -0.55 & -0.98 & -0.95 & -1.08 & -0.97 \\
\hline & $(0.15)^{\star \star \star}$ & $(0.41)$ & $(0.21)^{\star \star \star}$ & $(0.66)$ & $(0.24)^{\star \star \star}$ & $(0.68)$ \\
\hline \multirow[t]{2}{*}{ infodeficit } & -0.39 & -1.30 & & & & \\
\hline & $(0.12)^{\star \star \star}$ & $(0.30)^{\star \star \star}$ & & & & \\
\hline \multirow[t]{2}{*}{ info } & & & & & -0.20 & -0.61 \\
\hline & & & & & $(0.11)^{\star}$ & $(0.30)^{\star \star}$ \\
\hline info2 & & & -0.25 & -0.57 & & \\
\hline & & & $(0.11)^{\star \star}$ & $(0.30)^{\star}$ & & \\
\hline Observations & 1500 & 1500 & 779 & 779 & 627 & 627 \\
\hline Pseudo R2 & & & & & & \\
\hline
\end{tabular}

Notes: Standard errors in parentheses* significant at 10\%; ${ }^{\star \star}$ significant at 5\%; ${ }^{\star \star \star}$ significant at 1\%. Shrink here takes the value 1 if the respondent is in favour of either reform option, -1 if the respondent is strictly against one of the two reforms and does not approve the other and 0 otherwise. 


\section{Annex 2}

The questions used to define the variable "noclue"

\section{Questions}

Some people speak of a possible crisis in our public pension system. As a consequence, in 10/15 years time we would not be able to keep public pensions at their current level. Do you agree with this opinion?

1. Yes, I agree

2. No, I don't agree

3. Refused

4. Don't know

Do you think that in the course of the next 10 years there will be another pension reform reducing significantly the amounts of public pensions?
1. Yes
2. No
3. Refused
4. Don't know

As you probably know, in Italy there were several pension reforms within the last years. Which of the following statements does in your opinion describe best the results of these pension reforms? The reforms...

1. Stabilized the pension system: there's no need for another reform

2. Were just a first step: new reforms are necessary

3. Did not succeed in stabilizing the system: a new reform will be soon necessary

4. Refused

5. Don't know

According to you, the government should...

1. Reduce taxes and compulsory contributions and, at the same time, cut pensions, unemployment benefits, and social assistance

2. Maintain taxes and compulsory contributions, etc. at current levels

3. Increase pensions, unemployment benefits, social assistance, by raising taxes and compulsory contributions

4. Refused

5. Don't know

According to you, the government should...

1. Allocate more resources to pensions and less to unemployed or young jobseekers

2. Allocate less resources to pensions and more to unemployed or young jobseekers

3. Let the situation unchanged

4. Refused

5. Don't know

Currently women can retire earlier than men. In light of the financial problems of public pension system, do you think it would be fair if they retired at the same age?

1. Yes, I think it would be fair

2. No, I think it wouldn't be fair

3. Refused

4. Don't know

The recent pension reforms put more emphasis on own provision for retirement, and less on the state. Do you think is fair?
1. Yes
2. No
3. Refused
4. Don't know

Do you think that private pension plans are a better deal than the cost public pension system, i.e., provide benefit per a higher pension benefit per $\$$ contribution paid?

1. Yes

2. No

3. Refused

4. Don't know

If older people would retire later, would this affect job opportunities for younger people?

1. Younger people would have less opportunities

2. Younger people would have the same opportunities

3. Younger people would have the same opportunities

4. Refused 


\begin{tabular}{|c|c|}
\hline 5. & Don't know \\
\hline \multicolumn{2}{|r|}{$\begin{array}{l}\text { Which of the following institutions does best represent your own interests in the pension reform } \\
\text { debate? }\end{array}$} \\
\hline 1. & The Government \\
\hline 2. & The opposition \\
\hline 3. & Trade Union \\
\hline 4. & "Confindustria" \\
\hline 5. & Pension experts and commissions \\
\hline 6. & European Union \\
\hline 7. & Refused \\
\hline 8. & Don't know \\
\hline \multicolumn{2}{|r|}{ Do you think the influence of the trade unions on the pension reform debate is today... } \\
\hline 6. & Too weak \\
\hline 7. & Right \\
\hline 8. & Too strong \\
\hline & Refused \\
\hline 10. & Don't know \\
\hline \multicolumn{2}{|r|}{$\begin{array}{l}\text { Do you think the influence of the pension experts and commissions on the pension reform debate } \\
\text { is today... }\end{array}$} \\
\hline 1. & Too weak \\
\hline 2. & Right \\
\hline 3. & Too strong \\
\hline 4. & Refused \\
\hline 5. & Don't know \\
\hline \multicolumn{2}{|r|}{ Do you think the influence of the EU on the pension reform debate is today... } \\
\hline 1. & Too weak \\
\hline 2. & Right \\
\hline 3. & Too strong \\
\hline 4. & Refused \\
\hline 5. & Don't know \\
\hline
\end{tabular}




\section{Annex 3}

\section{Glossary of the key variables}

\begin{tabular}{|c|c|c|c|}
\hline Variable & Values & Description & Sample \\
\hline \multirow[t]{3}{*}{ Shrink } & 1 & $\begin{array}{l}\text { in favour of cutting pension benefits and/or increasing retirement } \\
\text { age }\end{array}$ & \multirow[t]{3}{*}{ all } \\
\hline & -1 & against at least one policy option and not in favour of the other & \\
\hline & - & "don't know" / "no answer" on both questions & \\
\hline \multirow[t]{2}{*}{ info_deficit } & 1 & the respondent is aware of the fact the pension system is in deficit & \multirow[t]{2}{*}{ all } \\
\hline & 0 & otherwise & \\
\hline \multirow[t]{2}{*}{ info_payg } & 1 & $\begin{array}{l}\text { the interviewee knows that the public pension contributions are } \\
\text { used only to pay pension benefits to current pensioner. }\end{array}$ & \multirow[t]{2}{*}{ employed } \\
\hline & 0 & otherwise & \\
\hline \multirow[t]{2}{*}{ info_rate } & 1 & $\begin{array}{l}\text { the interviewee is aware of which percentage of his wage is used } \\
\text { to pay pension contributions. }\end{array}$ & \multirow[t]{2}{*}{ employees } \\
\hline & 0 & otherwise & \\
\hline \multirow[t]{3}{*}{ info2 } & 2 & $\begin{array}{l}\text { both infodeficit and infopayg are equal to one (the interviewee } \\
\text { knew that both the pension system is in deficit and the public } \\
\text { pension contributions are used only to pay pension benefits to } \\
\text { current pensioner) }\end{array}$ & \multirow[t]{3}{*}{ employed } \\
\hline & 1 & either infodeficit or infopayg are equal to one. & \\
\hline & 0 & $\begin{array}{l}\text { both infodeficit and infopayg are equal to zero (i.e. the interviewee } \\
\text { gave the wrong answer to both questions). }\end{array}$ & \\
\hline \multirow[t]{4}{*}{ info3 } & 3 & $\begin{array}{l}\text { infodeficit, infopayg, infocostind are all equal to one (i.e. three } \\
\text { correct answers about the pension system functioning). }\end{array}$ & \multirow[t]{4}{*}{ employees } \\
\hline & 2 & $\begin{array}{l}\text { the respondent gave two correct answer out of three questions } \\
\text { about the knowledge of the pension system. }\end{array}$ & \\
\hline & 1 & $\begin{array}{l}\text { it takes value one if the interviewee give just one correct answer } \\
\text { out of three. }\end{array}$ & \\
\hline & 0 & none of the answers is correct & \\
\hline \multirow[t]{2}{*}{ Male } & 1 & male & \multirow[t]{2}{*}{ all } \\
\hline & 0 & female & \\
\hline \multirow[t]{2}{*}{ married } & 1 & the interviewee is married or widowed & \\
\hline & 0 & otherwise & \\
\hline \multirow[t]{2}{*}{ Old } & 1 & the interviewee was born before 1949 & \multirow[t]{2}{*}{ all } \\
\hline & 0 & otherwise & \\
\hline \multirow[t]{2}{*}{ young } & 1 & the interviewee was born after 1970 & \multirow[t]{2}{*}{ all } \\
\hline & 0 & otherwise & \\
\hline \multirow[t]{2}{*}{ university } & 1 & interviewee' higher school degree is the university degree or more & \multirow[t]{2}{*}{ all } \\
\hline & 0 & otherwise & \\
\hline \multirow[t]{2}{*}{ compulsory } & & the interviewee has a compulsory school degree or less & \multirow[t]{2}{*}{ all } \\
\hline & & otherwise & \\
\hline \multirow[t]{2}{*}{ children } & 1 & the breadwinner has at least one child living in the household & \multirow[t]{2}{*}{ all } \\
\hline & 0 & the breadwinner doesn't have any children & \\
\hline \multirow[t]{2}{*}{ pensioner } & 1 & the interviewee retired & \multirow[t]{2}{*}{ all } \\
\hline & 0 & otherwise & \\
\hline town & 1 & city dimension (number of citizens) up to 30 thousands & all \\
\hline & 0 & otherwise & \\
\hline city & 1 & city dimension (number of citizens) more than 100 thousands & all \\
\hline & 0 & otherwise & \\
\hline whitecollar & 1 & the interviewee is a whitecollar worker & all \\
\hline & 0 & otherwise & \\
\hline bluecollar & 1 & the interviewee is a bluecollar worker & all \\
\hline
\end{tabular}




\begin{tabular}{|c|c|c|c|}
\hline & 0 & otherwise & \\
\hline \multirow[t]{2}{*}{ headpens } & 1 & the breadwinner is a pensioner & \multirow[t]{2}{*}{ all } \\
\hline & 0 & otherwise & \\
\hline \multirow[t]{2}{*}{ planearly } & 1 & the interviewee plans to retire before age of 60 & \multirow[t]{2}{*}{ all } \\
\hline & 0 & otherwise & \\
\hline \multirow[t]{2}{*}{$\operatorname{dini}$} & 1 & concerned by the Dini pension system reform & \multirow[t]{2}{*}{ all } \\
\hline & 0 & otherwise & \\
\hline \multirow[t]{2}{*}{ id_left } & 1 & $\begin{array}{l}\text { the interviewee defines his political position between } 0 \text { and } 3 \text { on a } \\
\text { decimal left-right scale, where } 0 \text { represents extreme left and } 10 \\
\text { extreme right }\end{array}$ & \multirow[t]{2}{*}{ all } \\
\hline & 0 & otherwise & \\
\hline \multirow[t]{2}{*}{ id_right } & 1 & $\begin{array}{l}\text { the interviewee defines his political position between } 7 \text { and } 10 \text { on a } \\
\text { decimal left-right scale, where } 0 \text { represents extreme left and } 10 \\
\text { extreme right }\end{array}$ & \multirow[t]{2}{*}{ all } \\
\hline & 0 & otherwise & \\
\hline \multirow[t]{2}{*}{ crisis } & 1 & $\begin{array}{l}\text { it is likely that will be a crisis of the pension system in a ten/fifteen } \\
\text { years time }\end{array}$ & \multirow[t]{2}{*}{ all } \\
\hline & 0 & otherwise & \\
\hline \multirow[t]{2}{*}{ involvement } & 1 & $\begin{array}{l}\text { the interviewee red newspaper, articles / watched TV programs } \\
\text { concerning pension reform debate }\end{array}$ & \multirow[t]{2}{*}{ all } \\
\hline & 0 & otherwise & \\
\hline \multirow[t]{4}{*}{ attention } & 4 & $\begin{array}{l}\text { interviewee' level of attention in following current pension debate is } \\
\text { high }\end{array}$ & \multirow[t]{4}{*}{ all } \\
\hline & 3 & medium & \\
\hline & 2 & low & \\
\hline & 1 & none & \\
\hline \multirow[t]{2}{*}{ expert } & 1 & $\begin{array}{l}\text { the influence of the pension experts and commissions on the } \\
\text { pension reform is today too weak }\end{array}$ & \multirow[t]{2}{*}{ all } \\
\hline & 0 & otherwise & \\
\hline \multirow[t]{2}{*}{ union } & 1 & $\begin{array}{l}\text { the interviewee is a member of a tradeunion or he thinks that the } \\
\text { influence of unions on the pension reform is today too weak (or } \\
\text { both) }\end{array}$ & \\
\hline & 0 & otherwise & \\
\hline noclue & $\begin{array}{l}\text { from } 0 \text { to } \\
13\end{array}$ & $\begin{array}{l}\text { how many times an interviewee answered "I don't know" the } \\
\text { questions of the survey. The questions on pension reforms are not } \\
\text { included }\end{array}$ & all \\
\hline
\end{tabular}




\section{Annex 4}

\section{Sample questions of questionnaire}

\begin{tabular}{|c|c|c|}
\hline Issues & Questions & Variables \\
\hline \multirow[t]{2}{*}{$\begin{array}{l}\text { Opinions on pension } \\
\text { reforms }\end{array}$} & $\begin{array}{l}\text { Are you in favour of increasing retirement age? } \\
\text { 1. I'm in favour } \\
\text { 2. I'm against } \\
\text { 3. I don't know }\end{array}$ & shrink \\
\hline & $\begin{array}{l}\text { Are you in favour of reducing pension benefits? } \\
\text { 1. I'm in favour } \\
\text { 2. I'm against } \\
\text { 3. I don't know }\end{array}$ & shrink \\
\hline \multirow[t]{3}{*}{$\begin{array}{l}\text { Informazion about } \\
\text { the costs and } \\
\text { functioning of the } \\
\text { Italian pension } \\
\text { system }\end{array}$} & $\begin{array}{l}\text { Given all the contributions paid by employees and employers, and all the } \\
\text { pension benefits paid to current pensioners, do you think that our public } \\
\text { pension system is... } \\
\text { 5. balanced (the sum of all the contributions is equal to the total } \\
\text { expenditure for paying pension benefits), } \\
\text { 6. in surplus (the sum of all the contributions is lager than the total } \\
\text { expenditure for paying pension benefits, allowing to save } \\
\text { resources for the future), } \\
\text { 7. in deficit (the sum of all the contributions is lager than the total } \\
\text { expenditure for paying pension benefits, requiring to use } \\
\text { additional taxes to finance public pension system) } \\
\text { 8. refused } \\
\text { 9. I don't know }\end{array}$ & info_deficit \\
\hline & $\begin{array}{l}\text { According to you, for which purpose are these contributions used for?, } \\
6 . \text { only to pay your own future pension, } \\
\text { 7. only to pay pension benefits to current pensioners, } \\
\text { 8. to pay both your own future pension and current pensions, } \\
\text { 9. refused } \\
\text { 10. I don't know }\end{array}$ & info_payg \\
\hline & $\begin{array}{l}\text { As you probably know, in Italy both employees and employers pay public } \\
\text { pension contribution. Which percentage of your wage is used to pay } \\
\text { pension scheme contributions? (take in account also the contribution paid } \\
\text { by your employer), } \\
\text { less than } 10 \% \\
\text { 6. } 10 \%-15 \% \\
\text { 7. } 15 \%-20 \% \\
\text { 8. } 20 \%-25 \% \\
\text { 9. } 25 \%-30 \% \\
\text { 10. } 30 \%-35 \% \\
\text { 11. } 35 \%-40 \% \\
\text { 12. more than } 40 \% \\
\text { 13. refused } \\
\text { 14. I don't know }\end{array}$ & info_rate \\
\hline \multirow[t]{2}{*}{$\begin{array}{l}\text { Involvement in public } \\
\text { debate and } \\
\text { information }\end{array}$} & $\begin{array}{l}\text { Which was your level of attention in following current pension reform } \\
\text { debate? } \\
\text { 5. high } \\
6 . \text { medium } \\
7 . \text { low } \\
8 . \text { none }\end{array}$ & attention \\
\hline & $\begin{array}{l}\text { During the last months, have you read newspaper articles/watched TV } \\
\text { programs concerning pension reform debate?, } \\
\text { 1. yes } \\
2 . \text { no }\end{array}$ & involvement \\
\hline
\end{tabular}

